\title{
Leseopplæring og fagenes literacy
}

\author{
Atle Skaftun ${ }^{\star}$, \\ Professor, Norwegian Reading Centre, University of Stavanger, Norway
}

\begin{abstract}
-norsk
Artikkelen er opprinnelig publisert i Leseboka. Leseopplering $i$ alle fag (Skaftun, Solheim, \& Uppstad, 2015), og er et forsøk på å formulere et helhetlig perspektiv på lesing og literacy som bakgrunn for å forstå leseopplæring og fagenes literacy. Ulike forskningsinteresser blir knyttet sammen ved at literacy diskuteres som et spørsmål om tilgang på tre nivå: til skriften, til teksten og til tekstkulturen. Denne forståelsesrammen legges til grunn for å beskrive literacy opplæringen i skolen som en prosess der elevene kan inviteres til å delta i fagspesifikke og mer generelt et akademisk fellesskap. Kjernen i dette fellesskapet er en ambisjon om å stimulere elevenes språklige tenking gjennom erfaring med ulike tenkemåter i de ulike fagene, slik at de samlet tilegner seg et mangfold av strategier å velge blant $\mathrm{i}$ møtet med tekster og situasjoner som kaller på forståelse og sunn dømmekraft. Et slikt helhetlig perspektiv på literacy tilfører dybde til forståelsen av lesing som grunnleggende ferdighet.
\end{abstract}

Nøkkelord: Leseopplaring; literacy; fagenes literacy; tilgangskompetanse

\begin{abstract}
- engelsk
This article is originally published as part of Leseboka. Leseopplaring $i$ alle fag (Skaftun, Solheim, \& Uppstad, 2015). It represents an attempt at establishing an integrated perspective on literacy education and literacy in the school disciplines. Different research interests are tied together in a discussion of literacy as a matter of access on three levels: On the level of the written code, of the textual meaning, and that of participation in a text culture. This framework is applied in a description of literacy education as a process where the students may be invited to take part in subject-specific and a more general academic community. The core value in this community is an ambition to stimulate the use of language as a means of thinking by providing experience from the different subjects. As a result, the students should aquire a repertoire of strategies and an ability to choose from this repertoire in a flexible way when facing texts and situations calling for sound judgement. An integrated perspective on literacy might add depth to the understanding of basic literacy skills.
\end{abstract}

Keywords: literacy education; literacy in the disciplines; access and participation

Received: September 2015; Accepted: September 2015; Published: September 2015

Opplæringen i skolen foregår innenfor politiske, institusjonelle, kulturelle, sosiale, pedagogiske og faglige rammer, som endrer seg over tid. De siste tiårene har endringene akselerert, med stadig kortere tid mellom skolereformene og nye læreplaner (1974, 1987, 1997, 2006). Den siste-Kunnskapsløftet fra 2006 (revidert 2013) —er et forsøk

${ }^{\star}$ Correspondence to: Atle Skaftun, Norwegian Reading Centre, University of Stavanger, Norway. Email: atle.skaftun@uis.no 


\section{A. Skaftun}

på å unngå stadige snuoperasjoner ved å gå bort fra svært spesifikke læreplaner og i stedet skissere rammer for undervisningen og opplæringsmål av mer generell karakter. ${ }^{1}$ Opplæringen skal selvfølgelig gi fagspesifikke kunnskaper, men læreplanen fokuserer også på at elevene skal utvikle kompetanser som går på tvers av fagene: De skal lære seg å regne, å lese, å skrive, å uttrykke seg muntlig og å bruke dataverktøy på en faglig god måte. I den norske læreplanen er denne kompetansen knyttet til beskrivelsen av fem grunnleggende ferdigheter.

Etter innføringen av Kunnskapsløftet i 2006 har det vært mye fokus på å få skoler og lærere til å arbeide med grunnleggende ferdigheter - særlig lesing - i alle fag og gjennom hele skoleløpet. Det er imidlertid en stor oppgave å omsette slike ideer til praksis, og evalueringer av hvordan den nye læreplanen er blitt satt ut i livet, viser at mye arbeid gjenstår. Det er mye usikkerhet knyttet til forståelsen av grunnleggende ferdigheter blant lærere og skoleledere; en vanlig oppfatning er at ordet grunnleggende peker mot elementere ferdigheter, altså noe man lærer først, og så er ferdig med (Hertzberg, 2009). Når det gjelder lesing, er det nærliggende å tenke på begynneropplæring og mestring av skriftspråkskoden. Intensjonen med å løfte fram de grunnleggende ferdighetene i Kunnskapsløftet favner imidlertid både bredere og dypere enn som så. Det handler om ferdigheter som noe som utvikles kontinuerlig i samspill med fagenes tenke- og arbeidsmåter og om deltakelse i faglige praksiser.

Når Kjell Lars Berge kaller Kunnskapsløftet en literacy-reform (Berge, 2005) er det fordi oppmerksomheten rettes mer eksplisitt mot hvordan man bruker språk og skriftspråk som redskaper i de enkelte fagene. I et slikt literacy-perspektiv lærer elevene ikke bare faglig innhold, men også fagspesifikke måter å forstå, snakke, lese og skrive på. Begrepet literacy er lånt inn fra engelsk og brukes i økende grad uoversatt på norsk (Skaftun, 2009; Skjelbred \& Veum, 2013). Dette kapittelet tar sikte på å belyse hva literacy er og hvordan begrepet kan være til hjelp når vi ønsker å etablere et helhetlig perspektiv på lesing. I det som følger skal vi bevege oss fra kulturnivå til individnivå - fra skriftkulturelle fellesskap til individuelle leseferdigheter-før vi runder av med å samle trådene $\mathrm{i}$ en diskusjon av lesing som en grunnleggende ferdighet. Et gjennomgående perspektiv i framstillingen er at literacy handler om tilgang på ulike nivå: Det handler om å komme inn $i$ skriften, teksten, og inn $i$ tekstkulturen.

\section{Literacy og tilgang}

Det engelske ordet literacy har en lang og kronglete historie. Literate i betydningen utdannet eller bokkyndig kan spores tilbake til 1432, mens ordet illiterate dukker opp i 1556 (Barton, 1994). Begrepet illiteracy kan dateres til 1660, mens literacy dukker opp første gang i 1883. Utover 1900-tallet har literacy-begrepet fătt stadig nye betydninger og bruksområder. En av de sterkeste betydningene er som en metafor for kompetanse, slik vi ser det i begreper som computer literacy eller for den saks skyld

\footnotetext{
${ }^{1}$ I stedet for reformer har vi fătt revisjoner og justeringer av læreplanene. Den siste versjonen kom høsten 2013.
} 
i pleonasmen reading literacy, som måles i de store internasjonale leseundersøkelsene PIRLS og PISA (Gabrielsen \& Solheim, 2013; Kjærnsli \& Olsen, 2013; Mullis, Martin, Kennedy, Trong, \& Sainsbury, 2009; OECD, 2010). I det moderne skriftintensive kunnskapssamfunnet er skriftkyndighet i økende grad en forutsetning for å delta. Denne innsikten ligger til grunn for at OECD definerer reading literacy som evnen til å «forstå, bruke, reflektere over og engasjere seg i skrevne tekster, for å kunne nå sine mål, utvikle sine kunnskaper og evner og delta i samfunnet» (Kjærnsli \& Olsen, 2013, p. 178). Den samme innsikten ligger til grunn for fokuset på grunnleggende ferdigheter $i$ Kunnskapsløftet.

Lesing handler om tilgang på flere nivå. Det handler om å komme inn i skriften, og på det grunnlaget bli i stand til å komme inn $i$ tekstenes meningsverden. Når man har funnet veien inn, handler den videre utviklingen også om å komme ut av teksten og innta en selvstendig og myndig holdning til teksten. Lesing handler derfor om å komme inn $i$ et skriftkulturelt fellesskap. ${ }^{2}$ Literacy favner om alle disse aspektene ved lesing (Skaftun, 2009; Skjelbred \& Veum, 2013). Literacy er altså sammensatt, det er både et kognitivt og et sosialt fenomen. Som med mange andre sosiale fenomen, finnes det også ulike oppfatninger av hva fenomenet er og hvordan vi skal forholde oss til det.

Literacy-begrepet bærer altså med seg flere betydninger på samme tid. I en slik flertydighet ligger det også til rette for uenighet og strid om hva som skal regnes som literacy, ikke minst i forbindelse med skole og utdanning. Brian Street peker på to ytterpunkter i forståelsen av hva literacy er: den autonome og den ideologiske forståelsen (Street, 1984). Den første betrakter lesing og literacy som en ferdighet som elevene i større eller mindre grad har. I et slikt perspektiv er leseferdighet en selvstendig og universell størrelse som kan studeres og oppøves uavhengig av kulturelle forhold. Den ideologiske forståelsesmodellen, derimot, peker på at det finnes noen måter å bruke tekster på som blir regnet som mer verdifulle enn andre, og at samme tekstpraksis blir vurdert ulikt av ulike grupper i samfunnet. Det betyr at literacy er et omstridt fenomen, et sosialt gode som ikke alle har like lett tilgang til.

Sosial bakgrunn er en av de faktorene som påvirker elevenes muligheter i skolen mest (Knudsen, 1980). Slike mekanismer er det ganske lett å se i land med større sosiale forskjeller enn i Norge. Shirley Brice Heath viste i en epokegjørende studie (Heath, 1983) hvordan barn som begynner på skolen, er sosialisert inn i ulike måter å forholde seg til tekst og boklig kunnskap på. Barn fra den øvre middelklassen vokser opp i et hjemmemiljø med verdier knyttet til skrift og lesing som er dypt beslektet med de verdiene de møter på skolen. Slike verdier viser seg for eksempel i det at man leser skjønnlitteratur for barna på sengekanten. Når barna begynner på skolen, ligger alt til rette for at middelklassebarna føler seg hjemme der, og at de blir sett og anerkjent som flinke og smarte av lærerne. Og omvendt vil barn uten denne bakgrunnen oppleve skolen som mer fremmed, og lærerne vil kanskje oppleve dem som fjerne eller til og med mindre smarte. I begge tilfellene er det et spørsmål om hvorvidt elevene møter sin egen eller en fremmed kultur på skolen.

\footnotetext{
${ }^{2}$ Bjørn Nicolaysen foreslår tilgangskompetanse (Nicolaysen, 2005) som oversettelse av literacy.
} 


\section{A. Skaftun}

James Paul Gee har studert slike ulikheter i det amerikanske samfunnet (Gee, 1996). Han legger vekt på å beskrive karakteristiske trekk ved lite privilegerte afroamerikanske miljøer på deres egne premisser, altså ikke som mangelfulle i forhold til den dominerende kulturens kjennetegn. Han finner for eksempel en måte å snakke sammen og dele historier på i dette fellesskapet, som han betrakter som et utpreget muntlig fellesskap, der det å sammenlikne og skape analogier er høyt verdsatt. Denne formen for poetisk muntlighet blir ikke sett eller verdsatt når barna blir bedt om å fortelle historier i klasserommet - ikke før langt senere i utdanningsløpet. Det som forventes av de små er en mer lineær fortellingsstruktur, og veien er kort til å tenke at barna er svake når det kommer til narrativ kompetanse, samtidig som deres styrke ikke blir sett.

Gees forslag til hvordan man kan møte og kompensere for slike motsetninger, er større kulturell selvbevissthet fra skolens side og dermed også at skolens tenkemåterdet som er innforstått og selvfølgelig for dem som allerede er innenfor-blir synliggjort for elevene. I Norge er nok forskjellene mindre, men også her er det mye klokskap å hente om hvordan kulturelle forskjeller spiller inn på det som foregår $\mathrm{i}$ klasserommet. Å utvikle en god praksis er et prinsipp som kan realiseres på mange måter. Eksplisitt opplæring i lesestrategier er en måte å sette ord på noen av de praksisene som kommer av seg selv for de mest privilegerte. Med utgangspunkt i Gee er slik opplæring en systematisk måte å motarbeide at sosiale forskjeller forsterkes i skolen. I dette perspektivet, der strategiopplæring handler om å sørge for at alle får tilgang til reglene i spillet, ligger det også en sunn påminnelse om at strategier er nettopp midler til et mål, og ikke nødvendigvis et mål i seg selv.

Kulturmøtene i klasserommet rommer mange dilemmaer. Man risikerer at elever distanserer seg fra skolekulturen fordi den ikke er forenlig med deres egne verdier. Eller omvendt, man risikerer å kolonialisere elever som underkaster seg skolekulturen selv om den strider mot deres egne verdier. Slike kulturelle konfliktlinjer er det flere av, og ofte vil de være sammensatte. Det kan handle om etnisk tilhørighet, slik Jonas Hassan Khemiri beskriver i sin dagbokroman Et øye rødt (Khemiri, 2006). Romanen handler om en ung gutt som rives mellom en identitet som svensk og en som arabisk. En liknende konflikt finner vi i Arne Garborgs roman Bondestudentar (Garborg, 1883), men her møter vi de kulturelle konfliktlinjene innenfor norsk kultur, mellom bondekultur og skolens verdsetting av borgerlig bykultur.

I vår tids digitale hverdag er barn og unge aktive deltakere i tekstkulturer utenfor skolen. I dette ligger det et markant brudd med skolens funksjon som hovedinngang til det tekstkulturelle fellesskapet, slik den i stor grad har vært det før datamaskinens tid. Her ligger det en kime til nye konfliktlinjer mellom skolens og de unges tekstkulturelle identiteter. Når elevene er på skolen, gir Internett dem anledning til å forlate klasserommet og gå inn og ut av slike rom (Blikstad-Balas, 2012), og noen frykter at kvaliteten på elevenes leseforståelse kan forringes hvis skjermen erstatter papiret som dominerende leseflate (Mangen, Walgermo, \& Brønnick, 2013). Men den digitale tekstkulturen gir også mange spennende muligheter og utfordringer for framtidens skole. Mange mener at skolen er gammeldags, og at store deler av barns læring foregår i andre kontekster enn i skolen (Gee, 2013; Gee \& Hayes, 2011; 
Lankshear \& Knobel, 2003; Nygard, 2013). Spørsmålet om hva som er den beste måten å drive «Fremtidens skole» på er et aktuelt tema (Ludvigsen-utvalget, udatert), og det finnes ulike syn, som illustrerer at literacy er et omstridt fenomen, ikke minst knyttet til bruken av pc og Internett i klasserommet. Samtidig er de fleste enige $i$ at skolen forvalter en tradisjon for kunnskap og tenkning som det er vanskelig å kaste fra seg. Og selv om det finnes mange historier om enkeltpersoner som har snudd skoletap til suksess i arbeidslivet, så er det ikke til å komme forbi at det å lykkes i skolen for langt de fleste har stor betydning for muligheter senere i livet. I det som følger skal vi utforske nærmere hva som kjennetegner skolens og fagenes literacy.

\section{Skolens og fagenes literacy}

Det finnes mange nisjer innenfor tekstkulturene, som alle har sine spesielle koder for hvordan man opptrer. Skole, arbeid og fritid er noen slike nisjer med spesifikke krav og forventninger til måten man bruker språk og skrift på. Skolespråket er for eksempel mer eksplisitt enn hverdagsspråket (Bernstein, 1964; Gee, 1996). Blant venner og familie vil veldig mye av det vi snakker om være underforstått, og det som er underforstått trenger vi ikke si. Fordi det ikke blir uttalt, kalles ofte denne formen for felles verdier, vurderinger og viten for taus kunnskap (Polanyi, 1982). I skolesammenheng er det vanlig å prøve å unngå at samtaler og undervisning bygger på slik kunnskap; det å forklare hva ord og uttrykk betyr er viktig for at elevene skal forstå det som læreren og lærebøkene har å fortelle. Vel så viktig og kanskje enda vanskeligere er det for elevene selv å venne seg til skolens måte å organisere kunnskap på. God bruk av tale- og skriftspråk på skolen kjennetegnes for eksempel av at en konklusjon følger logisk av en rekke premisser; at et synspunkt underbygges og forklares på en måte som giør det mulig å ta stilling til det; at en forklaring henger sammen, er logisk og så videre.

På skolen kommer elevene inn i faglige fellesskap som strekker seg fra første klasse til forskningsfronten og Nobel-prisen. Det finnes selvsagt viktige forskjeller mellom skole- og forskningsfag, men det finnes også vesentlige likhetstrekk som knytter dem sammen. Det betyr at forholdet mellom skolefag og forskningsfag kan-eller måtolkes; forholdet er imidlertid ikke entydig bestemt. I denne boka velger vi å legge vekt på noen sentrale fellestrekk heller enn ulikhetene. Kjerneverdien $\mathrm{i}$ all skolering er kunnskap og logisk tenkning som grunnlag for menneskelig dømmekraft. Det viktigste verktøyet i den sammenhengen er tale- og skriftspråk som tankeredskap. Det språket som verdsettes i skolen, i høyere utdanning og i forskning har til felles et knippe med verdier knyttet til vitenskapelig språk og vitenskapelige forklaringer. Vi vil gjerne at det skal være så presist som mulig og samtidig så klart som mulig, og vi ønsker at det skal være mulig å etterprøve det som blir sagt. Gjennom 13 års skolegang foredles og utvikles språket kontinuerlig, og de som fortsetter med høyere utdanning, fortsetter utviklingen på en mer avgrenset og selvvalgt faglig arena (se kapittel 3). Akademia er et gammelt ord som opprinnelig er knyttet til skolegang og vitenskapelige verdier. I vår tid er det ofte brukt om en yrkesgruppe - akademikere —eller som adjektiv—akademisk —og da ofte forbundet med en form for livsfjern og 


\section{A. Skaftun}

unødig komplisert måte å tenke på. Kanskje vi heller skal ta ordet tilbake som en mer nøktern betegnelse for de faglige fellesskapene som elevene kommer i berøring med når de begynner på skolen?

Innenfor dette akademiske fellesskapet har alle det til felles at de lærer nye ting og utvikler seg hele tiden. De lærer av personer som er bedre kvalifisert enn dem selv, de lærer av de som er på samme nivå som dem selv, og de lærer av å hjelpe dem som er kommet kortere enn dem selv - alt sammen tett knyttet til arbeid med tekster: tekster man leser og tekster man skriver selv. Å komme inn i dette fellesskapet handler om å tilegne seg en måte å tenke, vurdere og handle på som er i tråd med de akademiske verdiene; en konstruktiv måte å forholde seg til at kunnskap alltid kan formuleres på andre måter og at presisjon og klarhet er verdier som kan brukes til å formulere det man vet, enda bedre.

Det er ingen selvfølge at alle kommer inn i det akademiske fellesskapet som skolen utgjør. Det er lett å gjøre narr av statistikken som forteller at antall bøker i hjemmet bestemmer hvor godt barn presterer på skolen. Det er selvsagt ikke bøkene i seg selv som bestemmer, men snarere at størrelsen på bokhyllen henger tett sammen med foreldrenes utdanning og deres forhold til bøker, lesing og kunnskap. Et hjemmemiljø som verdsetter utdanning og skolekunnskap forbereder barnet på å gå inn i skolespråket, og ofte er overgangen nokså smertefri. Oppvekst i et hjemmemiljø som aktivt unngår å identifisere seg med skolen, gjør det langt vanskeligere for barnet å finne seg til rette i skolen. I tillegg til sosioøkonomisk bakgrunn er også kulturell bakgrunn en av de viktige faktorene som kan være en ekstra terskel for tilgang til det akademiske fellesskapet. Barn som ikke har skolespråket-altså norsk - som morsmål, mangler ofte en form for dybde i språket; de forstår det meste, og ingen reagerer nevneverdig på språket deres i hverdagen. Men nettopp i møtet med skolens språk, det eksplisitte, presise og begrepsmessige språket, er det mange som ikke klarer eller forstår betydningen av å kople seg på. Engasjement er et mangetydig ord, som ofte reduseres til å bety begeistring, og dermed lett knyttes til ytre forhold med underholdningsverdi. Kjernen i ordet er imidlertid nettopp denne formen for kopling mellom individet og det som foregår (Guthrie \& Wigfield, 2000; Skaftun, 2011; se også kapittel 4); altså at eleven engasjerer sin egen kunnskap og erfaring i møte med en oppgave eller situasjon. Engasjement i et slikt perspektiv er et mål for elevens utvikling, ikke et middel. Målet for den faglige utviklingen er at eleven bygger en relevant kunnskaps- og erfaringsbase og ikke minst en beredskap for å bruke erfaringsbasen i faglige situasjoner.

Skolens og vitenskapenes språk er altså typisk eksplisitt, presist og innrettet mot abstrakte begreper, men skolen har ikke alltid vært like eksplisitt $i$ å vise og forklare dette for elevene. At skolen til en viss grad er preget av taus kunnskap, ser vi i at koden i skolen har vært tatt for gitt. Det fungerer fint for alle som er beredt til å møte denne koden hjemmefra, men ikke for de som ikke er forberedt eller til og med er motvillig innstilt. Når vi snakker om akademisk literacy, har vi tatt et skritt i retning for å bøte på dette. Ved å sette ord på og synligjøre den språklige praksisen i skolen, blir det mulig å inkludere flere i fellesskapet. 
Så langt har vi snakket om generelle kjennetegn ved akademisk literacy, altså ting som gjelder alle fag. Men også fagene har sine særtrekk og sine koder for hvordan man organiserer og formulerer faglig kunnskap. På veien fra første skoletrinn til høyere studier og forskning får eleven i økende grad anledning til å velge faglig fokus og spesialisering. I skoleløpet fra trinn 1 til 13 må elevene kunne opptre på en kvalifisert måte i en rekke fag. Når de er i en mattetime, må de tenke, snakke, vurdere og handle på mattefagets premisser; i historietimen må de agere historikere, og i norsktimene er de invitert inn som del av det norskfaglige fellesskapet. Innenfor de enkelte fagene gjenkjenner vi akademisk literacy som faglighet, altså at eleven inntar og fyller en rolle $\mathrm{i}$ arbeidet med faget som læreren med fagtradisjonen i ryggen kjenner igjen som meningsfull.

Fagene skiller seg fra hverandre på en rekke områder. De uttrykkes skriftlig i forskjellige sjangre, de vektlegger forskjellige tankeoperasjoner, de har ulike stilideal for både tale og skrift, og sist men ikke minst, de kan ha forskjellig ordforråd. I naturfag er rapporten en særpreget sjanger, som sjelden brukes i andre fag. I slike tekster er det viktig å tilegne seg en mal som kan gjenkjennes som vitenskapelig-dette er for eksempel ikke plassen for nyskapende fantasiutfoldelse. Å bruke maler disiplinerer både tanken og språket og gjør det mulig for eleven å opptre på en måte som gjenkjennes som passende av det faglige fellesskapet av elever og lærere. Tekstene er ofte sammensatt av ord og setninger, figurer og tabeller. Momentene organiseres i avsnitt i en bestemt rekkefølge, som utstyrsliste, prosedyre, hypotese og resultat, og målet vil være å forklare det som er observert. Stilen er knapp, kompakt, nøktern og objektiv, og ofte preget av fagbegreper (se kapittel 6). Matematikkens tekster kan være helt uten verbalspråk, men de kan også være helt avhengige av verbalspråklige elementer for å være leselige. Å forklare framgangsmåten i matematisk problemløsning på en eksplisitt måte, er krevende, og grundig modellering er nyttig. I matematikk verdsettes svar som det kan settes to streker under, for dermed å markere at svaret er sant (se kapittel 5). I samfunnsfagene og de humanistiske fagene tenker man litt annerledes, der er det andre teksttyper som viser slike tenkemåter. Akademisk literacy (Langer, 2010) handler dermed også om å kunne mestre særtrekk i ulike fag, om å opptre faglig på fagets premisser.

Språk og tanke hører nøye sammen, og ulike situasjoner inviterer til ulike måter å både tenke og å bruke språket på. På skolen lærer elevene å bruke skriftspråket, og de lærer å tenke på og å snakke om det de allerede vet av egen erfaring. I hverdagslig erfaring er det større rom for å tenke at alt henger sammen med alt. På skolen lærer elevene å dele opp de store sammenhengene ved hjelp av begreper, og de studerer ulike erfaringsområder innenfor ulike fag med sine særpregede måter å være vitenskapelige på. Alt dette inngår i tilegnelsen av akademisk literacy, og livsnerven i denne sammensatte kompetansen er tenkning med språklige redskaper.

\section{Språk og tenkning}

Det er ikke bare på skolen eller i vitenskapen man bruker språket til å tenke med. Den russiske psykologen Lev Vygotskij (1896-1934) beskriver individets vei inn i et 


\section{A. Skaftun}

språklig fellesskap som en dialektisk prosess på flere nivå (Vygotskij, 2001). For det første oppstår det en forbindelse mellom tenkning og det talte ord, som innebærer at ordet blir et redskap for tanken. Denne formen for tenkning - språklig tenkningutvikles over lang tid. Til å begynne med er ordet et overflatisk tegn for barnet, som mangler erfaring med hva ordet refererer til. Denne erfaringen vokser langsomt, og barnet blir etter hvert i stand til å bruke ordet mer treffsikkert. I denne prosessen bruker barnet språket til å ordne verden etter beste evne, det er ingen snarvei til den allerede eksisterende ordningen av verden som språket som sådan viser til. Denne ordenen hører voksenperspektivet til, og kjennetegnes i sin mest avanserte form av tenkning i begreper, altså at ord har sin mening i forhold til andre ord på en helhetlig logisk måte. Den begrepsmessige tenkningen dyrkes i sin reneste form i skole og vitenskap. Barnet kommer til skolen midt i en språklig utviklingsprosess som for de fleste hovedsakelig er basert på hverdagslig erfaring med det som skjer i deres egen verden. På skolen møtes hverdagsspråket og et mer abstrakt språk med begreper og definisjoner. Rommet mellom det som er erfart og uordnet på den ene siden og abstrakte begreper som, på den andre siden, kan ordne erfaringen, kaller Vygotskij den ncermeste utviklingssonen (Vygotskij, 2001).

I rommet mellom elevenes språklige erfaring og den vitenskapelige kunnskapen, som er ordnet systematisk i begreper og kategorier, bistår skolen og lærerne elevene i å utvikle sine evner til å bruke språket til å tenke med. Elevene kommer til skolen med masse erfaring og sin egen forståelse av tilværelsen. På skolen lærer de mye de ikke vet noe om fra før, men i stor grad handler det også om å lære det de allerede vet på stadig nye måter, eller snarere formulert stadig mer presist. Dette er et prinsipp som vi finner igjen i hele utdanningsløpet.

Et eksempel: De fleste skolestartere er proppfulle av fortellerglede, og skolen legger til rette for at de skal få uttrykke seg muntlig, og etter hvert skriftlig. Elevene er ikke gamle før de møter en fortellingsmodell med begynnelse, midte og sluttformet som en fisk, for eksempel. Slike modeller representerer en første teoretisering av fortellingens form. På ungdomstrinnet forventes det i økende grad at elevene skal utvikle et analytisk blikk på fortellinger, og elevene som velger studiespesialisering på videregående, møter den litterære analysen som sentral skriftlig oppgavesjanger. Her vil noen også møte Aristoteles sin definisjon av den gode fabelens struktur. De som fortsetter som studenter i litteratur eller språkfag, vil garantert møte Aristoteles sin klassiker Om diktekunsten (Aristoteles, 2004) på pensumlisten. Denne progresjonen gjennom utdanningsløpet kan vi beskrive som en bevegelse fra erfaringsbasert forståelse av hva en fortelling er, til teoretisk innsikt i fortellingen som fenomen. La oss se på et annet eksempel, fra kompetansemålene i samfunnsfag for 10. trinn: ${ }^{3}$

Drøfte ideer og krefter som førte til den amerikanske frihetskampen og den franske revolusjonen, og følger dette fikk for den demokratiske utviklinga i Norge.

\footnotetext{
${ }^{3}$ I kapittel 2 brukes dette kompetansemålet som gjennomgående eksempel. Se også kapittel 3 om vokabular.
} 
Dette er utpreget faglig språk, preget av abstrakte begreper og kategorier som er forankret i historie som vitenskapsfag. «Krefter» betyr for eksempel noe annet i denne sammenhengen enn i fysikken og skolens naturfag, og «ideer» refererer snarere til filosofihistorien enn til enkeltpersoners plutselige påfunn eller smarte oppfinnelser. Hva som «førte til», slik det står her, er en annen måte å si «årsaker til», og det henger nøye sammen med «følger». Også det å «drøfte» er en generell abstraksjon som ikke alle elevene skjønner til bunns, og samtidig er drøfting av årsaker og virkninger en svært sentral og spesifikk tenkemåte i historiefaget. De store revolusjonene er vanligvis et av de første temaene i samfunnsfag på ungdomstrinnet. Med utgangspunkt i dette kompetansemålet ligger det til rette for aktivt arbeid i elevenes nærmeste utviklingssone. Det kan være klokt å peke ut mestring av dette språket og den historiefaglige tenkemåten som langsiktig mål for samfunnsfaget (10.trinn), for så å dvele ved og forsøke å anskueliggjøre begrepene slik at elevene kan knytte dem til det språket og de erfaringene de har med seg når de begynner på ungdomstrinnet. Å diskutere andre betydninger av sentrale ord $i$ andre fag og andre sammenhenger, som vi har indikert ovenfor er en måte, en annen kan være å aktivere erfaringer som er gjenkjennelige for elevene, og som kan illustrere årsaksforhold generelt og, mer spesielt, hvordan ideer kan skape endring i det små, og hvordan vi kan snakke om «krefter» som metafor i beskrivelsen av samfunnsforhold. Aktivt arbeid i elevenes nærmeste utviklingssone handler slik sett om å skape forbindelser mellom de abstrakte begrepene og noe som er gjenkjennelig for elevene.

Utviklingen av begrepsmessig tenkning er en komplisert prosess, men samtidig bør den være lett gjenkjennelig hvis vi tillater oss å aktivere vår egen erfaringsbakgrunn. Vygotskij tyr til mange sammenlikninger for å illustrere poenget sitt. En av de viktigste er å sammenlikne med det å lære seg et nytt språk. I tilegnelsen av morsmålet mestrer vi de mest primitive sidene ved språket lenge før vi mestrer de mest komplekse. Vi får på plass tonefall, språklyder og grammatiske og syntaktiske konvensjoner lenge før vi lærer å identifisere og være oss bevisst disse sidene av språket. Når vi lærer et fremmedspråk, er forholdet omvendt. Da lærer vi ofte grammatiske regler og øver på uttale av enkeltlyder, mens den lette og sikre bruken av språket er sluttproduktet.

Sammenlikningen mellom utvikling av begrepsmessig tekning og det å lære et nytt språk har sine begrensninger. Men den viser likevel at - og hvordan - to forskjellige læringsprosesser virker inn på hverandre. Når man lærer det andre språket, gjør man seg nytte av å allerede kunne et språk, samtidig som det å lære et nytt språk påvirker hvordan man forholder seg til det første språket. Det er altså ikke en gjentakelse av den samme prosessen når man lærer seg språk nummer to. Erfaring med morsmålet fyller ut de abstrakte formene - ofte grammatiske - man møter når man lærer et nytt språk, mens de abstrakte formene gjør det mulig å få et bevisst forhold til morsmålet og egen erfaring. Vygotskij beskriver dette samspillet med en metafor som å rydde en vei mellom erfaring og abstrakt begrepsmessig tenkning. Veien ryddes fra begge kanter samtidig:

Når et dagligdags begrep baner seg vei oppover, baner det samtidig veien for det vitenskapelige begrepet og dets utvikling nedover. [...] Vitenskapelige begreper på 


\section{A. Skaftun}

sin side strukturerer for den oppadgående utviklingen av barnets spontane begreper i retning av bevissthet og viljesstyrt bruk av dem. Vitenskapelige begreper vokser nedover med hjelp av spontane begreper, spontane begreper vokser oppover med hjelp av vitenskapelige begreper. (Vygotskij, 2001, p. 171)

Metaforen peker på tre svært viktige poeng. For det første holder den fram elevens erfaring og den akademiske tradisjonen som like viktig i læringsprosessen. For det andre gir den oss en forståelsesramme for hva det vil si å utvikle dypere forståelse av et fenomen: Det er en læringsprosess som innebærer at kunnskapen ordnes i begrepskategorier, samtidig som kunnskapen oppleves som en del av ens egen erfaring. For det tredje løfter den fram språkutvikling som redskap for læring og kognitiv utvikling. Utviklingen foregår i samspillet mellom det de kan fra før, og det de kan få til med litt hjelp - i den nermeste utviklingssonen, som Vygotskij kaller det.

Denne forståelsen av læring finner vi igjen i svært mye pedagogisk tenkning fra de siste 30 årene. Skolens oppgave er å rydde veien for elevenes utvikling fra den akademiske siden, og samtidig engasjere elevene slik at de kommer i gang med ryddearbeidet fra sin kant, kunne vi si i forlengelsen av metaforen til Vygotskij. Den danske pedagogen Vibeke Hetmar (Hetmar, 1996, 2009) beskriver klasseromssituasjonen som et møte mellom elevenes ikke-spesialiserte forståelse av faget - elevfaglighetpå den ene siden og lærernes spesialiserte forståelse av faget—lererfaglighet - på den andre siden. Disse to måtene å være faglige på møtes innenfor skolen som institusjon, med svært spesifikke forventninger til hvordan både lærere og elever skal oppføre seg. Den amerikanske psykologen Jerome Bruner beskriver samspillet mellom den som lærer og den mer kvalifiserte andre som stillasbygging (Bruner, 1986, p. 74). Læreren er en støtte for eleven slik at hun kan rekke høyere enn hun ville greid på egen hånd.

Vi har dvelt ved språket som redskap for tanken, og hvordan møtet mellom hverdagens og skolens språk skaper en utviklingssone for den enkelte eleven. Skriftspråket har en viktig plass i dette møtet, ettersom skolens og fagenes språk og tenkemåter er så tett knyttet til bruk av skrift og tekster. Leseopplæring i et slikt perspektiv handler om å tilegne seg måter å tenke på som gjør at man kan forstå mer enn enkeltord og overflatemeningen i en tekst. Målet er elever som forstår hva tekstene vil fortelle, og som også kan innta en kritisk posisjon til det de leser når det er nødvendig.

Vi har støttet oss til Vygotskijs beskrivelse av hvordan den språklige tenkningen utvikles i møtet mellom hverdagsspråk og skolens mer begrepslige språk. Det er en utvikling fra forankring i konkret erfaring til mer abstrakt tenkning. Skriftspråket er til stor hjelp i denne utviklingen. Skriften gjør språket synlig og konstant, der talen er tilgjengelig kun gjennom hørselen i et øyeblikk. Å mestre skriftspråk er i seg selv et kompakt illustrasjonsbilde på hvordan den språklige tenkningen utvikler seg, fra å være bundet til individets egen opplevelsesverden her og nå, til å lære å stige ut av strømmen av øyeblikk og betrakte opplevelsen og reflektere over den. Leseopplæring skal hjelpe elevene over flere terskler på veien mot en slik moden og myndig posisjon der man kan forholde seg selvstendig til det man leser i lys av den sammenhengen teksten inngår $i$. 


\section{Literacy og lesing}

Vi har sett at literacy handler om tilgang til skriften, til tekstlig innhold og til det kulturelle fellesskapet tekstene hører hjemme i. Skolens literacy er ett slikt fellesskap blant mange og er knyttet til den måten vi bruker språk og tekst på i skole og utdanning. Innenfor det store akademiske fellesskapet har de ulike fagene sine særtrekk som gjør at vi også kan snakke om fagenes literacy. På alle nivå handler det om tilgang til språklige praksiser og tenkemåter som blir tilgjengelige i skolen, om å komme inn eller stå utenfor, om å bli inkludert eller ekskludert.

Når vi leser, gjør vi oss våre egne forestillinger om det vi har lest, sier litteratur- og lesepedagogen Judith Langer (Langer, 1995, 2010). Det er imidlertid ikke en enkel byggeprosess, der vi legger stein på stein til vi er ferdig; det er ikke tilstrekkelig å lese ord etter ord for å bygge slike forestillinger. Vi må ha en idé om helheten, om hvordan byggverket skal se ut, og hvordan de enkelte delene skal passe inn i helheten. Når vi leser, har vi forventninger om hva som kommer, men gode lesere er på vakt for signaler som viser at forventningene må justeres.

Langer beskriver lesing som en bevegelse mellom ulike posisjoner og de bildene eller forestillingene av helheten man forsøker å danne seg (Langer, 1995, 2010). Hun beskriver fem slike posisjoner: ${ }^{4}$

1) utenfor på vei inn,

2) innenfor på vei gjennom,

3) ut igjen for å revurdere det man vet, og

4) ut igjen for å objektivere den nye erfaringen

5) ut og videre til nye erfaringer

Det er ingen fast rekkefølge mellom disse posisjonene. De representerer posisjoner vi flytter oss mellom for å møte ulike utfordringer underveis i lesingen. Avhengig av hvor man er i lesingen, er det noen lesemåter eller strategier som er kloke å bruke. La oss dvele litt ved hva disse posisjonene innebærer i tur og orden.

1) Før vi går i gang, vil vi ofte være relativt åpne for hva teksten har å si. I skolen er det anbefalt praksis å aktivere forkunnskap i denne posisjonen før man begynner å lese, slik at man har en foreløpig helhetsforståelse fra starten av. 2) Når vi er i gang, må vi være lojale mot tekstens egen logikk og fange opp mest mulig av det den inneholder. På den måten bygger vi opp et bilde innenfra av hva teksten handler om, kan vi si. 3) Underveis og etterpå vil vi kunne relatere teksten til det vi tror og vet, og enten revidere vår egen forståelse eller la kunnskapen vår bestemme hvordan vi vurderer teksten. For å gjøre slike vurderinger, må vi ut av teksten og innta en betraktende posisjon utenfor vår egen forståelse av teksten. Hvis vi er i tvil eller hvis vi arbeider med et tema med flere synspunkter, vil vi kanskje sjekke andre kilder.

\footnotetext{
${ }^{4}$ Langers engelske termer er being out and moving into an envisionment, 2) being in and moving through an envisionment, 3) stepping out and rethinking what one knows, 4) stepping out and objectifying the experience, og 5) leaving an envisionment and going beyond (Langer, 2010, s. 23). Jf. Skaftun, 2009 for en diskusjon av Langers teori i litteraturfaglig lys.
} 


\section{A. Skaftun}

4) Den fjerde posisjonen handler i større grad om å reflektere over teksten som tekstover formelle virkemidler, komposisjon, sjanger og så videre. 5) Den siste posisjonen handler om at lesearbeidet og de forstillingene som er etablert, følger med leseren også etter at lesingen er avsluttet, og utgjør en del av den erfaringen som leseren møter nye lesesituasjoner med.

Det finnes mange forskjellige teksttyper og mangfoldet er stort også innenfor en og samme teksttype eller sjanger. En leser med et stort register av lesemåter er i stand til å tilpasse seg ulike tekster og situasjoner, og velge en hensiktsmessig framgangsmåte som passer til formålet med lesingen. Å skumlese et dikt som forberedelse til en litterær samtale i klasserommet eller i gruppearbeid, er ikke et hensiktsmessig valg av lesemåte. Men hvis man skal finne et dikt som passer til en bestemt anledning, er det kanskje ikke så dumt å velge denne lesemåten. Det er ikke noe nytt at man leser og sammenlikner flere tekster om samme tema i skole og forskning. For ungdomsskoleeleven er det en kjent oppgave å søke i ulike kilder og velge de som er mest relevante som grunnlag for egen skriving eller muntlige presentasjoner. Den digitale hverdagen understreker enda tydeligere at lesingen ofte foregår i det som kalles multiple tekster (Fox \& Alexander, 2009); altså at lesing i og utenfor skolen ofte er en relasjon mellom en leser og flere tekster-ikke bare $e n$. Langers beskrivelse av leserens posisjonering og forholdet til egne forestillinger av tekster, lar seg overføre til denne situasjonen. Bildet kompliseres ved at det er flere forestillinger som skal relateres til hverandre og leserens egen forståelse av temaet. Den underliggende logikken i at vi flytter oss mellom å være innenfor og utenfor, er en enkel beskrivelse av forståelsesprosessen generelt som synes å ha gyldighet også i tilknytning til lesing av flere tekster.

Langer beskriver to grunnholdninger eller tenkemåter hos leseren som må til for å skape mening (Langer, 1995, 2010): 1) å fastholde et referansepunkt og 2) utforske mulighetshorisonter. ${ }^{5}$ Den første kjennetegnes av vi har et helhetsbilde av emnet eller teksten som referansepunkt, og samler informasion og begreper som klargiør, utdyper, eller modifiserer helhetsforståelsen. Lesing av fagtekster egner seg godt til å illustrere denne målrettede lesemåten. Det er hensiktsmessig å skaffe seg oversikt over teksten ved å bruke strategier for forhåndslesing, det vil si å lese med penn $\mathrm{i}$ hånden $\mathrm{og}$ notere underveis, og når man er ferdig, kan det være lurt å skrive et kort resymé. Når vi leser på denne måten, vil vi forsøke å fjerne tvetydighet og bygge opp et nettverk av sammenhenger rundt det referansepunktet som vi startet lesingen med. Små justeringer forekommer, men vi gir ikke slipp på referansepunktet uten videre. Dersom det hoper seg opp med motstridende informasjon, kan vi bli nødt til å oppgi referansepunktet og innse at vi tok feil. Da tvinges vi ut i en mer utforskende tenkemåte.

Den andre tenkemåten er ikke styrt av en fast helhetsforståelse, men kjennetegnes snarere av at vi må være åpne for at helhetsforståelsen hele tiden er i endring, og ikke minst av at vi må akseptere dette vilkåret for meningsproduksjon. Leseren er innstilt på å rekognosere i ukjent landskap, og teksten byr på flere tolkningsmuligheter, som vi mer eller mindre bevisst velger å forfølge videre. Skjønnlitteratur er det mest

\footnotetext{
${ }^{5}$ Langer bygger på Louise Rosenblatts tilsvarende skille mellom efferent og estetisk lesing (Rosenblatt, 1995).
} 
åpenbare eksempelet på tekster som krever en slik utforskende lesemåte. Leser man en fagtekst på 5-10 sider som elev eller student, er det ofte lurt å skumme litt og kanskje lese en eventuell oppsummering. Men for lesehesten som skal begynne på en tykk roman som han har gledet seg til, er ikke det hensiktsmessig; det ville ødelagt noe av opplevelsen av romanen. Opplevelsen henger nøye sammen med det å bli overrasket, fengslet, skuffet, bekymret, begeistret og så videre etter hvert som handlingen skrider framover.

Men den åpne holdningen til teksten kan ikke reduseres til det å søke spenning eller underholdning. Og den kan heller ikke avgrenses til lesing av skjønnlitteratur. Og det er heller ikke slik at vi alltid leser skjønnlitteratur på den utforskende måten. I litterær analyse på skolen og på universitetet, må man ofte lese om igjen for å sjekke antakelser og finne steder i teksten som understreker de poengene man vil ha fram. Hvis man for eksempel har en idé om at Hamsun er en kvinnehater eller at moderne kvinnelige forfattere har sviktet kvinnekampens idealer, må man lese flere bøker, med et spesifikt referansepunkt for øye. Og når man leser fag- og saktekster, er det viktig å være åpen for andre sammenhenger enn de man allerede tror man har oversikt over. På den måten utvider man kunnskap og forståelse om et emne. Ikke minst når man leser noe man vet lite om fra før, vil det ofte være klokt å bruke tid, lese nøye og være åpen for at helhetsforståelsen kan endre seg. Noen ganger kan man også bli overrasket og fanget inn i tankebaner som fengsler og fascinerer på en måte som ikke står tilbake for liknende reaksjoner på skjønnlitteratur. Plutselige innsikter som velter om på det man vet; en god formulering som plutselig gir svar på et spørsmål man har båret på lenge.

Poenget må være at de to måtene å forholde seg til mening på er fleksible ressurser på samme måte som de fem posisjonene man har om egne forestillinger. Begge er gode å ha uansett hva man leser. Den utforskende lesingen er kanskje den minst opplagte i dagens skole med sine mange eksplisitte målformuleringer, men kanskje nettopp derfor også en ressurs som det er ekstra viktig å rette oppmerksomheten mot i leseopplæringen.

\section{Grunnleggende ferdigheter og lesing}

De språklige ferdighetene er grunnleggende fordi de er redskaper til å tenke med. I skolen og i hvert enkelt fag dyrkes og utvikles evnen til å tenke språklig generelt, og den mer abstrakte måten å tenke på som kjennetegner bruken av skriftspråk spesielt. Judith Langer kaller det literate thinking (Langer, 2010). Skolen gir elevene tilgang til nye verdener. Når elevene har lært seg å lese bokstavene som tegn, har skriftens verden åpnet seg for dem. Vel inne i denne verdenen vil de møte en rekke tekster som de kan gå inn i og komme ut av med mer innsikt enn de hadde før de gikk inn. Ved å oppholde seg i den skriftlige verdenen vil de lære nye måter å tenke på, og de vil ha tilgang til nye posisjoner å se og forstå verden utenfor skriften på. De blir langsomt men sikkert en del av nye skriftkulturelle fellesskap, og de blir i stand til å posisjonere seg på en ansvarlig og selvstendig måte i et skriftintensivt samfunn som tilbyr et vell av mulige identiteter. I den digitale tidsalderen foregår slike prosesser i stor grad utenfor skolen 


\section{A. Skaftun}

(Gee \& Hayes, 2011). Men skolen er ikke desto mindre et sted der det ligger til rette for å øve og utvikle seg i mer kontrollerte omgivelser. Skriftspråklige ferdigheter handler generelt om å kunne ta inn og forstå, samt snakke og skrive om bilder av verden og på den måten være med og forme hvordan vi forstår verden rundt oss.

Vi har sett at literacy handler om tilgang til skriften, til tekstlig innhold og til det kulturelle fellesskapet tekstene hører hjemme i. Akademisk literacy er ett slikt fellesskap og er knyttet til den måten vi bruker språk og tekst på i skole og utdanning. Innenfor det store akademiske fellesskapet har fagene sine særtrekk som gjør at vi også kan snakke om fagenes literacy. På alle nivå handler det om tilgang til språklige praksiser, om å komme inn eller stå utenfor, om å bli inkludert eller ekskludert. Målet med undervisningen er at elevene skal utvikle og differensiere sin faglighet $\mathrm{i}$ skolearbeidet. På det grunnlaget skal elevene møte et svært komplekst og skriftintensivt arbeidsliv som myndige tenkende individer. Lesing er en nøkkel til en slik utvikling, og leseopplæring handler om å føre elevene inn i skriften, inn i teksten og videre fram mot deltakelse i det skriftkulturelle samfunnslivet.

\section{Litteratur}

Aristoteles. (2004). Om diktekunsten. Oslo: Cappelen Akademisk Forlag.

Barton, D. (1994). Literacy: An introduction to the ecology of written language. Oxford: Blackwell.

Berge, K. L. (2005). Skriving som grunnleggende ferdighet og som nasjonal prøve -ideologi og strategier. In A. J. Aasen \& S. Nome (Eds.), Det nye norskfaget (pp. 161-188). Bergen: Fagbokforlaget.

Bernstein, B. (1964). Elaborated and restricted codes: Their social origins and some consequences. American Anthropologist, 66(6 PART 2), 55-69.

Blikstad-Balas, M. (2012). Digital literacy in upper secondary school-what do students use their laptops for during teacher instruction? Nordic Fournal of Digital Literacy, 2, 2012.

Bruner, J. S. (1986). Actual minds, possible worlds. Cambridge, MA: Harvard University Press.

Fox, E., \& Alexander, P. A. (2009). Text comprehension: A retrospective, perspective, and prospective. In S. E. Israel \& G. G. Duffy (Eds.), Handbook of research on reading comprehension (pp. 227-239). London: Routledge.

Gabrielsen, E., \& Solheim, R. G. (2013). Over kneiken? Leseferdighet på 4. og 5. trinn $i$ et tiårsperspektiv. Oslo: Akademika forlag.

Garborg, A. (1883). Bondestudentar. Skoleutgave ved Olav Midttun. Oslo: Aschehoug.

Gee, J. P. (1996). Social linguistics and literacies: Ideology in discourses. New York, NY: Routledge.

Gee, J. P. (2013). The anti-education era: Creating smarter students through digital learning. New York, NY: Palgrave Macmillan.

Gee, J. P., \& Hayes, E. R. (2011). Language and learning in the digital age. New York, NY: Routledge.

Guthrie, J. T., \& Wigfield, A. (2000). Engagement and motivation in reading. In M. L. Kamil, P. Mosenthal, P. D. Pearson, \& R. Barr (Eds.), Handbook of reading research, Vol. 3 (pp. 403-422). Manhaw, NJ: Lawrence Earlbaum Associates.

Heath, S. B. (1983). Ways with words: Language, life and work in communities and classrooms. New York, NY: Cambridge University Press.

Hertzberg, F. (2009). Skolen og grunnleggende ferdigheter. In J. Møller, T. S. Prøitz, \& P. Aasen (Eds.), Kunnskapsløftet - tung bør å bcere? Underveisanalyse av styringsreformen $i$ skjaringspunktet mellom politikk, administrasjon og profesjon. Nifu Step rapport 42/2009.

Hetmar, V. (1996). Litteraturpadagogik og elevfaglighed: Litteraturundervisning og elevernes littercere beredskab set fra en almenpæedagogisk position. Aarhus: Danmarks Lærerhøjskole.

Hetmar, V. (2009). Faglig lasning og skrivning i skolen: diskurser, positioneringer og rekontekstualisering. Oslo: Novus forlag.

Khemiri, J. H. (2006). Et øye rødt. Oslo: Gyldendal.

Kjærnsli, M. \& Olsen, R.V. (Eds.). (2013). Fortsatt en vei å gå. Norske elevers kompetanse $i$ matematikk, naturfag og lesing i PISA 2012. Oslo: Universitetsforlaget. 


\section{Leseopplaring og fagenes literacy}

Knudsen, K. (1980). Ulikhet i grunnskolen. Bergen: Universitetsforlaget.

Langer, J. A. (1995). Envisioning literature: Literary understanding and literature instruction. New York, NY: Teachers College Press.

Langer, J. A. (2010). Envisioning knowledge: Building literacy in the academic disciplines. New York, NY: Teachers College Press.

Lankshear, C., \& Knobel, M. (2003). New literacies: Changing knowledge and classroom learning. New York, NY: Open University Press.

Ludvigsen-utvalget. (udatert). Fremtidens skole. Retrieved from http://blogg.regjeringen.no/fremtidensskole/

Mangen, A., Walgermo, B. R., \& Brønnick, K. (2013). Reading linear texts on paper versus computer screen: Effects on reading comprehension. International fournal of Educational Research, 58, 61-68.

Mullis, I. V., Martin, M. O., Kennedy, A. M., Trong, K. L., \& Sainsbury, M. (2009). PIRLS 2011 assessment framework. Chestnut Hill, MA: TIMSS \& PIRLS International Study Center, Lynch School of education, Boston College.

Nicolaysen, B. K. (2005). Tilgangskompetanse: arbeid med tekst som kulturdeltaking. In B. K. Nicolaysen \& L. Aase (Eds.), Kulturmøte i tekstar: litteraturdidaktiske perspektiv (pp. 9-31). Oslo: Samlaget.

Nygard, A. O. (2013). Perforating school: Digital literacy in an arts and crafts class. In J. A. Ávila \& J. Z. Pandya (Eds.), Critical digital literacies as social praxis: Intersections and challenges. New Literacies and Digital Epistemologies, Vol. 54. New York, NY: Peter Lang.

OECD. (2010). PISA 2009 assessment framework: Key competencies in reading, mathematics and science. Paris: OECD.

Polanyi, M. (1982). Personal knowledge: Towards a post-critical philosophy. Chicago, IL: The University of Chicago Press.

Rosenblatt, L. M. (1995). Literature as exploration. New York, NY: Modern Language Association of America. Skaftun, A. (2009). Litteraturens nytteverdi. Bergen: Fagbokforlaget.

Skaftun, A. (2011). Understanding reading development: A phenomenological perspective. Educational Studies in Language and Literature, 11, 127-148.

Skjelbred, D., \& Veum, A. (Eds.). (2013). Literacy i leringskontekster. Oslo: Cappelen Damm Akademisk.

Street, B. (1984). Literacy in theory and practice. Cambridge: Cambridge University Press.

Vygotskij, L. S. (2001). Tenkning og tale. Oslo: Gyldendal Akademisk. 